\title{
Sustainable management of a marine protected area in Vietnam: An application of visitors' willingness to pay for conservation in $\mathrm{Cu}$ Lao Cham
}

\author{
Dang Thi Dieu Thuy (corresponding author) \\ Department of International Economics, \\ Thuongmai University, Hanoi, Vietnam. \\ Department of Financial and Business Systems, \\ Lincoln University, Christchurch, New Zealand. \\ dieuthuy.dang@gmail.com, thuy.dtd@tmu.edu.vn
}

\section{Christopher Gan}

Department of Financial and Business Systems,

Lincoln University, Christchurch, New Zealand.

\section{Baiding $\mathrm{Hu}$}

Department of Global Value Chains and Trade,

Lincoln University, Christchurch, New Zealand.

Publication Information:

Received 2 April 2021, Accepted 6 December 2021, Available online 28 December 2021

DOI: 10.21463/jmic.2021.10.2.05

\begin{abstract}
As an important area in terms of biodiversity and fish stocks in Vietnam, Cu Lao Cham or Cham Islands (CLC) marine protected area (MPA) is under increasing threat from human activities. Conservation efforts have recently been implemented but economic analysis of the CLC MPA's natural values did not investigate what may affect policy decisions on CLC MPA's sustainable development. Using a structured questionnaire and a payment card technique (based on the contingent valuation method), we estimate visitors' willingness to pay (WTP) for conservation of marine resources in the CLC MPA. The log-normal regression results indicate that the visitors' WTP for conservation is affected by their characteristics, perceptions of environmental protection and conservation, and their assessment of the current CLC MPA entrance fee. Visitors are WTP an additional amount of US\$2.26 per person for conservation while visiting the CLC MPA. This indicates that with the introduction of the proposed entrance fee (the mean WTP added to the current entrance fee), the CLC MPA management would not only have sufficient funds for their management and conservation programmes, but also that the number of visitors may decline slightly, which would reduce some of the pressure on the environment, natural resources, and coral reefs.
\end{abstract}

Keywords

Conservation, Cu Lao Cham, entrance fee, marine protected area, willingness to pay 


\section{Introduction}

The Vietnamese shoreline stretches over 3,200 km with over 3,000 islands. The country's coastal zones are densely populated and are currently experiencing critical changes in natural resource management. Rural coastal environments are traditionally considered marginal landscapes, the domain of poor coastal fishermen and others relying on livelihoods associated with the exploitation of open access resources (Brown, 2011). Because of easy access and high biodiversity, Vietnam's coastal resources generate benefits for economic development (e.g., from oil, gas extraction, fishery and tourism). However, human activities (industrialisation and urbanisation) impose serious negative impacts on coastal ecosystems (including coral reef habitats) (Sekhar, 2005). The development of tourism and other industries, and aquafarming have recently contributed to the transformation of the coastal zone, as part of the development driven by Vietnam's significant recent economic reforms and growth (Brown, 2011).

The Vietnam coast is also subject to natural disasters. Hurricanes periodically strike central coasts causing significant loss of life and shattering these areas for many years (Ngoc, 2018; Sekhar, 2005). The pressure on the coastal resources has risen through a combination of natural disasters, climate change, dramatic population growth and strong economic growth. These result in an unsustainable harvest of resources, increased environmental pollution and decreased productivity of the resources (Thang et al., 2011).

An economic valuation of marine protected areas (MPA) in Vietnam, including Cu Lao Cham (CLC) MPA, together with their biological and ecological values, is necessary for the development of a framework that ensures the efficient utilisation of marine and coastal resources in the context of social welfare based on public policy. Economic valuations provide a summary of the benefits associated with resource allocation; this information can be used to design sustainable measures to ensure the protection of marine resources in the MPAs (Emerton, 1999; Lipton et al., 1995).

Economic valuation studies show that visitors are willing to pay more than the current MPAs user fees (see Ahmed et al., 2005; Cesar, 2000; Peters and Hawkins, 2009) in addition to other funding sources (such as government funding, public donations or funding from other organisations), to help ensure MPA's financial sustainability. In CLC MPA, a user fee enables local authorities and the management board to manage the MPA with sufficient funds for management and conservation, and minimise the risk or damage to MPAs from increasing numbers of visitors. We investigate whether visitors are willing to pay for the conservation of CLC MPA by paying an additional entrance fee when visiting the CLC MPA. We also investigate the influence of visitors' socio-characteristics (e.g., income, education level, and occupation), their environmental perceptions and environmental education and their assessment of the current entrance fee on their WTP for conservation in the CLC MPA. The new entrance fee system was introduced to ensure the sustainable development of the CLC MPA and to promote efficient strategies for conservation and development in CLC.

\section{Study area}

Cham islands or Cu Lao Cham Marine Protected Area was established on 20 December 2005, under Decision No.88/2005/QD-UBND of the Provincial People's Committee of Quang Nam. It is recognised as a high biodiversity area including both protected marine waters and island nature reserves (Walton et al., 2015) (see Fig. 1). The aim of its establishment was to conserve marine natural resource biodiversity, environmental and cultural-historical values, improve community livelihoods, protect and effectively exploit ecosystems to ensure sustainable development (Trinh, 2006). The CLC archipelago consists of eight islands (Hon Lao, Hon Dai, Hon Mo, Hon Kho Me, Hon Kho Con, Hon La, 
Hon Tai, and Hon Ong) which lie $18 \mathrm{~km}$ offshore from Hoi An, an ancient town in the centre of Vietnam (Walton et al., 2015). In addition to its natural beauty, the CLC has an abundance of traditional/local knowledge and customs, archaeological sites, forest resources and medicinal plant resources (Tuan et al., 2004).

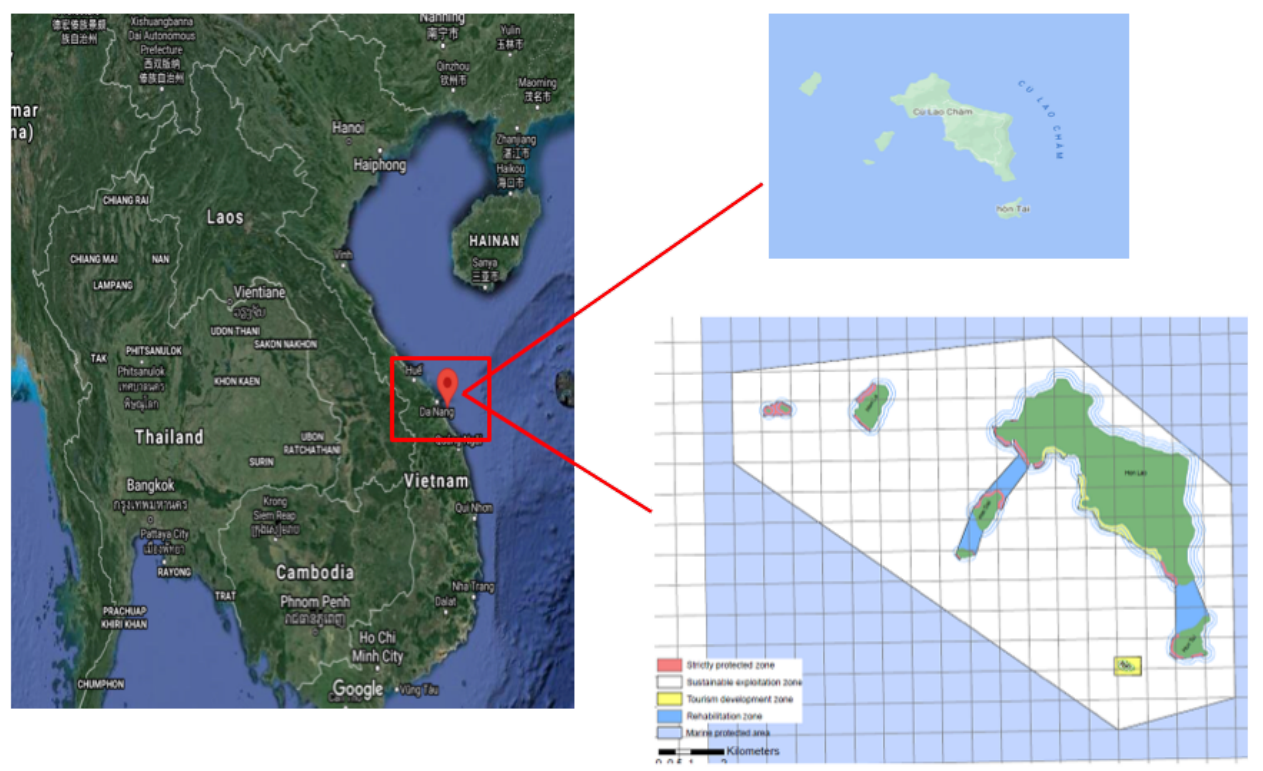

Fig 1. Location and functional zones of CLC MPA (Source: Google Maps, 2021; Trinh, 2006)

The CLC MPA covers an area of $235 \mathrm{~km}^{2}$ and consists of six functional zones (Fig. 1 bottom right). They are the core or strictly protected zone (the red area) $\left(1.26 \mathrm{~km}^{2}\right)$, the ecological rehabilitation zone $\left(2.25 \mathrm{~km}^{2}\right)$ (the blue area), the tourism development zone $\left(1.39 \mathrm{~km}^{2}\right)$ (the yellow area), the sustainable exploitation zone $\left(94.58 \mathrm{~km}^{2}\right)$ (the white area), the community development zone $\left(1.3 \mathrm{~km}^{2}\right)$, and the buffer zone $\left(120.02 \mathrm{~km}^{2}\right)$ (the light blue area) (Trinh, 2006; Walton et al., 2015).

Like other coastal areas and marine parks, CLC MPA is under pressure from development (Walton et al., 2015). Fishing activities in the CLC mostly take place onshore. Approximately $69 \%$ of the fish catch comes from a sustainable exploitation zone with sensitive ecosystems such as coral reefs or seagrass (Ngoc, 2018). Before its establishment, the natural resources and biodiversity in the CLC had decreased because of no environmental protection measures. The high demand for live edible fish, unsustainable fishing methods and near-shore reef fishing by poor residents all contribute toward marine resource over-exploitation. The conditions of the reefs and seagrass beds have also been altered (Ministry of Fishery (MOFI) and Danida, 2005). In addition, sand excavation, road construction, and oil and grease discharge from ships and boats have shortened the coastline and polluted CLC's beach environment (MOFI and Danida, 2005; Trinh, 2008).

The discharge of domestic waste into the sea, habitat degradation and destruction, marine productivity decline, biodiversity loss, and coastal pollution are problems confronting the CLC MPA (Long et al., 2008; Tin et al., 2019; Trinh, 2008). Long et al. (2008) indicate that some diseases on coral reefs came from residents' waste released on the beaches. This is a potential threat to the life and development of coral reefs and other related ecosystems in the CLC MPA. Tin et al. (2019) confirm that seagrass beds in the CLC MPA have faced significant changes from 2003 to 2017 as a consequence of marine pollution, changes in natural conditions and human activities. Sustainable development is then 
required to conserve a healthy coastal environment and marine resources because economic development and marine protection are inter-dependent in the coastal zone (MOFI and Danida, 2005). Moreover, the protection of coral reefs and related habitats in the CLC MPA provides fishery and tourism benefits, but only in the medium to longer-term under good management practices (MOFI and Danida, 2005; Trinh, 2008).

Before the reserve's establishment, fishing was the main income source for most households in the CLC MPA (Tri, 2007). Since 2009, when the CLC MPA was designated as a UNESCO biosphere reserve, the number of visitors has sharply increased, which has brought more income to the local households. In 2014, the tourist activities in the CLC MPA generated approximately US\$210,000 (Walton et al., 2015).

\section{Literature review}

In many developing and undeveloped countries, marine resources in coastal communities are undervalued because their economic value is not entirely recognised and estimated. This has started to change with more interest from economists, central and local government, and local people whose benefits are affected by marine resource overexploitation. Economic valuation provides a useful tool to capture sustainable development by specifying the importance of marine ecosystems to the economy in monetary terms. It also shows what a society may lose if marine ecosystems are not protected and preserved (Lange and Jiddawi, 2009). In addition, economic valuation provides vital information for policy planners so that they can factor in sustainability criteria in a market-based economy (Ledoux and Turner, 2002).

In terms of the total economic value of marine ecosystem goods and services, many scholars have examined specific characteristics of ecosystems in specific locations (e.g., Ahmed et al., 2007; Asafu-Adjaye and Tapsuwan, 2008; Carlsson et al., 2003; Chen et al., 2004; Christie et al., 2015). Asafu-Adjaye and Tapsuwan (2008) used the contingent valuation method (CVM) to value the benefits of scuba diving in the Mu Ko Similan Marine National Park, Thailand. Scuba divers at this site (both local and foreign divers) were asked if they were willing to pay (WTP) a diving fee for future visits. These estimates will be used to introduce an entrance fee system for the marine park. Christie et al. (2015) valued the benefits from marine and coastal ecosystem services in the proposed MPA in St Vincent and the Grenadines, Caribbean. The respondents were locals and visitors who visited the MPA. The authors included six ecosystem service attributes (fish, coastal protection, health, ecosystem, beach and diving) under two scenarios (decline and improvement compared with the MPA status quo). The WTP revealed that the respondents were willing to pay more for ecosystem services to avoid future degradation of the services; however, WTP values were more elastic between locals and visitors.

Several authors have reviewed previous studies to estimate the general values of marine and coastal resources globally (Akhter and Yew, 2013; Cicin-Sain, 2014; Costanza et al., 1997; de Groot et al., 2012; Martínez et al., 2007). Martínez et al. (2007) calculated the total economic value of the Ecosystem Services Product derived from the coastal ecosystem in 122 coastal countries. The total estimated value was US\$25.8 trillion per year. The authors emphasised that many coastal ecosystems are under construction (about $18 \%$ of the total land within $100 \mathrm{~km}$ of coasts). Although communities have increased their conservation efforts and introduced sustainable practices in marine areas, the impact of human activities (the transformation of natural habitats and coastlines, over-exploitation, and species invasion by human vectors) on marine resources continue. de Groot et al. (2012) screened over 320 publications (665 valuations) between 2007 and 2010 to provide a comprehensive overview of values of 22 services from natural resources. The authors' analysed the total economic value of 10 ecosystem services, which equalled 618,799 Int. $\$ /$ ha/year $^{1}$ at 2007 prices. The 
most valued services are from coral reefs and coastal wetlands, with an estimated cost of 352,249 Int.\$/ha/year and 193,845 Int.\$/ha/year, respectively. The economic valuation studies of single MPAs, marine parks or coastal areas focus on three main concerns: (1) appropriate valuation methods for (total or partial) marine resource valuation; (2) analyses of institutional financial sustainability for MPA management; and (3) the total estimated value of marine resources by visitors' or residents' stated or revealed preferences.

Scientists are more interested in estimating the economic value of coral reefs in MPAs, especially in developing countries (Ahmed et al., 2005; Ahmed et al., 2007; Rolfe and Gregg, 2012; Seenprachawong, 2005; Thur, 2004; Tongson and Dygico, 2004; Yeo, 2005). Dixon et al. (2000) investigated the economic valuation of coral reefs in the Bonaire Marine Park, Caribbean. In 1991, the marine park generated a total gross revenue of US\$23.2 million from diving tourism (returns generated from accommodation businesses, restaurants, dive shops and retailers, transport services, souvenir shops and other businesses). The authors recommended that the number of dives in all diving sites of the marine park should be between 190,000 and 200,000 per year (within the threshold of carrying capacity), but that could be maximised to 400,000 (with no or minimum effect to coral reefs) if the MPA implemented diver education and enhanced management. The total gross revenue from recreation-based tourism may increase by US\$20 million or more per year. Ahmed et al. (2007) estimate the benefits from coral reefs in Bolinao, the Philippines. The authors used the individual travel cost method and CVM to investigate visitor demand and the WTP for coral reef conservation. Their results show the economic value from the consumer surplus was US\$223 per visit or US\$4.7 million per year. The average WTP value for coral reef conservation is surprisingly low compared with other studies in the Philippines. It was only US\$0.45 per visit compared with US\$41 for the Tubbataha Reefs National Marine Park (Tongson and Dygico, 2004), US\$3.7 for Anilao, US\$5.5 for Mactan Island and US\$3.4 for Alona Beach (Arin and Kramer, 2002).

\section{Contingent valuation method - Payment card technique}

This study used the payment card technique from the CVM to estimate respondents' WTP for conservation when visiting the CLC MPA. The CVM, in general, often uses tax increase questions to elicit information about respondents' WTP on any change in environmental goods (Hall et al., 2002). However, this approach is not appropriate to analyse increases in the CLC MPA conservation tax or levy. The additional charge (added to the entrance fee) was used as a payment vehicle for non-use benefits. The payment card technique was used to elicit the mean WTP for conservation by visitors visiting CLC MPA. It was also used to investigate the determinants affecting the visitors' WTP for CLC MPA's conservation.

In the payment card technique, WTP values are introduced to the respondents with the lowest bidding value zero. The WTP values then increase at fixed intervals until the threshold value is achieved. Respondents are asked to choose their WTP from one of the values (Geleto, 2011). The payment card assumes that a series of WTP values will include the true WTP values that the respondents state for their WTP (Arin and Kramer, 2002). Based on the set of WTP values chosen by the respondents, the mean WTP is calculated to determine visitors' WTP for conservation in the MPA. Following Liu et al. (2019), the mean WTP is expressed in the equation (1):

$$
E(W T P)=\frac{1}{n} \sum_{t=1}^{n} B_{t} F_{t}
$$

Equation 1 
... where (1): $E(W T P)$ is the mean WTP of visitors; $B_{t}$ is the bidding value in the payment card with a series of $t$ values; $n$ is the total number of visitors; and $F_{t}$ is the number of visitors who state the bidding value $B_{t}$.

In this study, WTP responses are treated as interval valuations rather than point valuations (Cameron and Huppert, 1989; Hackl and Pruckner, 1999; Mathieu et al., 2003; Mahieu et al., 2012; Xu et al., 2006). This overcomes the problem of a true WTP value from the respondents by inferring that the respondents' WTP values are dropped within the interval values between the respondents' chosen value and the next highest value (Cameron and Huppert, 1989).

Ordinary least squares (OLS) or maximum likelihood estimates can be applied in the payment card CVM studies to investigate the determinants of WTP of visitors (Cameron and Huppert, 1989; Ghosh and Mondal, 2013; Lindsey and Holmes, 2002). However, the OLS estimate confronts an estimation problem if the payment values are in intervals rather than points. OLS estimation treats interval values at their interval midpoints giving a distorted result, an inequality between the expected values within the intervals and interval midpoints. Maximum likelihood estimation, on the other hand, has no bias problem with the interval valuation because the dependent variable in the regression models is estimated only on intervals on a continuous scale (Cameron and Huppert, 1989). In the maximum likelihood estimation, binary logistic regression, logistic regression or multiple regression may be used. If the WTP is a binary choice question, then the binary logistic regression is applied (Mathieu et al., 2003). Otherwise, multiple regression or multivariate analysis are preferred.

The lognormal distribution function of WTP is proposed in this study because the valuation distribution is regularly skewed to avoid negative values (Togridou et al., 2006). If $t_{u}$ and $t_{l}$ are the upper and lower threshold values in the interval values, the $W T P_{i}$ value of respondent $i$ will be between $t_{u i}$ and $t_{l i}$, then $\log \left(\mathrm{WTP}_{\mathrm{i}}\right)$ falls in the brackets of $\log \left(t_{u i}\right)$ and $\log \left(t_{l i}\right)$. The $\mathrm{WTP}_{\mathrm{i}}$ value for each respondent $i$ will be estimated using equation (2) (Cameron and Huppert, 1989):

$$
\log \left(W T P_{i}\right)=x_{i} \beta+\mu_{i}
$$

Equation 2

... where: WTP is the true value of WTP of respondent $i ; x_{i}$ is the vector of the respondent's characteristics; and $\mu_{\mathrm{i}}$ is a normally distributed error with mean zero and standard deviation $\sigma$.

The probability of both sides of equation (2) is given as follows (Cameron and Huppert, 1989; Mahieu et al., 2012):

$$
\operatorname{Pr}\left(\log \left(t_{l i}\right)<\log \left(W T P_{i}\right)<\log \left(t_{u i}\right)\right)=\operatorname{Pr}\left(\frac{\log _{l i}-x_{i}^{\prime} \beta}{\sigma}<z_{i}<\frac{\log _{u i}-x_{i}^{\prime} \beta}{\sigma}\right)
$$

Equation 3

... where: $z_{i}$ in equation (3) denotes the standard normal random variable. The probability in equation (3) is the result of the relationship between two different standard normal cumulative density functions $\left(G_{u i}\right.$ and $\left.G_{l i}\right)$ that represent the lower and upper limits of WTP values, $z_{l i}$ and $z_{u i}$, respectively. The probability of WTP $P_{i}$ of respondent $i$ will fall between these two threshold values $\left(G_{u i}-G_{l i}\right)$. Equation (3) is rewritten in the equation (4) as follows:

$$
\operatorname{Pr}\left(\log \left(t_{l i}\right)<\log \left(W T P_{i}\right)<\log \left(t_{u i}\right)\right)=G\left(z_{u i}\right)-G\left(z_{l i}\right)
$$


Equation (5) illustrates the corresponding log-likelihood function for the WTP with $n$ respondents:

$$
\log L=\sum_{i=1}^{n} \log \left[G\left(z_{u i}\right)-G\left(z_{l i}\right)\right]
$$

Equation 5

The fitted value of $\log \left(W T P_{i}\right)$ in equation (2) can be obtained when the optimal values of $\beta$ and $\sigma$ are estimated. The parameter $x_{i}^{\prime} \beta$ refers to the conditional mean of $\log \left(W T P_{i}\right)$ for any given vector of the $x$ variable. Therefore, the conditional distribution of WTP is retransformed; its median and mean are estimated as $\exp \left(x_{i}^{\prime} \beta\right)$ and $\exp \left(x_{i}^{\prime} \beta+\sigma^{2} / 2\right)$, respectively. However, the median WTP is preferred to the mean value, because the median value is considered a weighty unit for unobserved WTP central convergence and is less sensitive to the standard deviation of the random variable $\sigma$ (Cameron and Huppert, 1989; Xu et al., 2006).

Equation (6) expresses the empirical natural log-link function for the WTP used in this study for three groups of visitors: Vietnamese, foreign and combined visitors. Generalised Linear Models (with log normal distribution and Gamma family) in Stata 16.0 were used to determine the model fit. Table 5 defines the variables used in the three models.

$$
\begin{gathered}
\log (W T P)=\beta_{0}+\beta_{1} i n c+\beta_{2} \text { efrating }+\beta_{3} \text { manager }+\beta_{4} \text { secondary }+ \\
\beta_{5} \text { qltybeach }+\beta_{6} \text { envact }+B_{7} \text { valueCLC }+\beta_{8} \text { efincrease }+\beta_{9} \text { ecoedu }
\end{gathered}
$$

Equation 6

\section{Results and discussion}

Primary data obtained from visitors were used to determine their WTP for the CLC MPA conservation programme. The data were also used to investigate the factors that affect the visitors' WTP for conservation, such as visitors' demographics, environmental awareness, and their assessment of the entrance fee. The data were collected from structured questionnaires and face-to-face interviews between February and May 2018. A combination of yes/no questions, multiple-choice questions, five-point Likert scale questions, and open-ended questions were used in the questionnaire. The questionnaire aimed to obtain visitors' perceptions of environmental protection and conservation in MPAs, in general, their WTP for CLC MPA preservation, and their demographic data. Of the 556 collected questionnaires 505 questionnaires were useable for empirical analysis (a response rate $90.8 \%$ ). The surveyed respondents visiting the CLC MPA are both international and Vietnamese visitors. The two groups were analysed separately and then combined. The purpose of this was to test whether foreign visitors were willing to pay a higher conservation fee than Vietnamese visitors. The analysis includes investigating factors (such as socio-characteristics, environmental awareness, and current entrance fee evaluation) that affect the WTP for conservation by different groups of visitor.

Table 1 shows that most surveyed visitors understood the relationship between tourism and conservation in the CLC MPA. A five-point Likert scale (strongly disagree (1) to strongly agree (5)) was used to measure the visitors' opinions on the relationship between tourism and natural resource conservation. The visitors agreed that tourism should contribute to conservation efforts in the CLC MPA (mean 4.23); tourism should be combined with conservation to establish sustainable tourism (mean 4.18); and visitors' conservation awareness should be improved by integrating conservation education into tourism programmes (mean 4.0). They also agreed that maintaining coastal areas and marine resources 
is vital for the local community's future (mean 4.18). They disagreed that wildlife, marine creatures or fish stocks should be exploited for socio-economic or visitor development (means 2.19 and 1.96, respectively). They also disagreed that further development should be implemented (i.e., transforming natural areas into tourist entertainment venues, constructing more resorts/hotels or increasing the use of natural resources) (means of 2.15, 2.67 and 2.27, respectively). In short, the visitors were aware of the importance of protecting and conserving the marine resources and environment while tourism develops in the MPA.

Table 1. Visitors' perceptions of the relationship between tourism and conservation in Cu Lao Cham Marine Protected Area

\begin{tabular}{|c|c|c|c|c|c|}
\hline Statement & Obs. & Mean & S.D. & Min & Max \\
\hline Tourism should contribute to the conservation of the CLC MPA & 452 & 4.23 & 0.77 & 1 & 5 \\
\hline Tourism poses a risk to the nature and environment in the CLC MPA & 448 & 3.30 & 1.21 & 1 & 5 \\
\hline Visitor fees charged by the MPA are an effective way to fund conservation programmes & 450 & 3.84 & 0.89 & 1 & 5 \\
\hline It is important to protect the CLC MPA even if visitors will never visit them & 452 & 4.27 & 0.89 & 1 & 5 \\
\hline There is no interaction between tourism and conservation in the CLC MPA & 448 & 2.04 & 1.30 & 1 & 5 \\
\hline The development of eco-tourism will encourage local people to participate in community-based conservation & 445 & 4.07 & 0.81 & 1 & 5 \\
\hline Better conservation programme in the CLC MPA will result in better visitor outcomes & 446 & 3.95 & 0.90 & 1 & 5 \\
\hline Tourism and conservation may be combined into a sustainable tourism programme & 444 & 4.18 & 0.77 & 1 & 5 \\
\hline A conservation programme is a compulsory part of tourism & 442 & 4.00 & 0.94 & 1 & 5 \\
\hline Wildlife and native plants are exploited for local socio-economic development & 492 & 2.19 & 1.18 & 1 & 5 \\
\hline There should be more interactive activities with coral reefs and nature & 497 & 2.72 & 1.18 & 1 & 5 \\
\hline Coastal environment and natural resources should be fully used for visitors' enjoyment and relaxation & 499 & 2.27 & 1.23 & 1 & 5 \\
\hline More fishing to meet tourism demand & 499 & 1.96 & 1.08 & 1 & 5 \\
\hline Eco-tourism helps to strengthen the marine conservation effort & 500 & 3.67 & 1.19 & 1 & 5 \\
\hline Coastal areas and marine resources are important for the future of local people & 498 & 4.18 & 0.92 & 1 & 5 \\
\hline More resorts/hotels should be constructed to supply increased number of visitors & 496 & 2.67 & 1.34 & 1 & 5 \\
\hline More natural areas should be converted into tourist entertainment areas & 500 & 2.15 & 1.21 & 1 & 5 \\
\hline Total number of observations & 505 & & & & \\
\hline
\end{tabular}

The screening of the WTP questionnaire was first provided to visitors to eliminate protest bidders. The visitors were asked a yes/no question whether they were willing to pay extra (a positive amount) for conservation efforts in the CLC MPA. A significant proportion of visitors (33.66\%) were not willing to pay an additional entrance fee, suggesting that there were perhaps some protest bidders among the "No" visitors. According to Ghosh and Mondal (2013), protest bidders are surveyed visitors who chose one of the following reasons: "The MPA already has a fund for conservation"; "Polluters or fishermen should pay for conservation"; or "Not tourists' responsibility". The survey results show 111 "No" visitors ( $65.29 \%$ of "No" visitors or $21.98 \%$ of the total surveyed visitors) chose one, two or all three of the above reasons to explain why they would not pay an additional amount to support MPA conservation. These visitors were considered protest bidders and were excluded from the WTP model, because they would cause a downward bias in the WTP estimates (Hackl and Pruckner, 1999). Protest bidders are popular in CVM surveys (Asafu-Adjaye and Tapsuwan, 2008; Kerr, 2001; Wang and Jia, 2012). Latinopoulos et al. (2016) specified that a rate of protest bidders of $40 \%$ and below of the total surveyed respondents is acceptable in CVM studies. The "No" visitors who were not protest bidders, were considered valid zero bidders (Goodman et al., 1998). 
The results also show that 84 visitors (75.7\% of "No" visitors or $16.6 \%$ of total visitors) chose not to pay more (a positive amount) or an additional fee because they did not trust that the money would be used for conservation. It is likely that a lack of transparency in using funds by government agencies or authorities leads to visitors' distrust of these organisations' funds management. This behaviour is similar in other developing countries where public organisation funds are often misused. For example, surveyed divers in the coral reefs in Anilao, Mactan Island and Alona beach in the Philippines prefer that non-government organisations manage their fees, instead of government organisations (Arin and Kramer, 2002). Several surveyed respondents in China (19.7\%) were unwilling to pay for biodiversity conservation and environmental protection in the Dalai Lake protected area because they do not trust that their money would be used for these purposes (Wang and Jia, 2012).

After eliminating protest bidders, 394 observations were used for further analysis. The surveyed visitors' demographic characteristics are shown in Table 2. The three groups of visitors (Vietnamese, foreign and combined visitors) were analysed separately. In general, female visitors, younger visitors (age between 26 and 35), and higher educated visitors (with a bachelor degree and above) appeared to visit CLC MPA more. Approximately 60\% of visitors who visited the CLC MPA were professionals and business managers/owners/self-employed.

In the payment card format, visitors who answered "Yes" next picked their WTP value from the provided list of 10 bids. The "Yes" visitors were also provided with a list of WTP motivations (based on a five-point Likert scale) to validate of their positive bids (Goodman et al., 1998).

Table 2. The demographic characteristics of Cu Lao Cham Marine Protected Area's surveyed visitors (in percentages)

\begin{tabular}{|c|c|c|c|c|}
\hline Factor & Category & $\begin{array}{l}\text { Combined visitors } \\
\qquad(n=394)\end{array}$ & $\begin{array}{l}\text { Vietnamese visitors } \\
\qquad(n=325)\end{array}$ & Foreign visitors $(n=69)$ \\
\hline \multirow[t]{2}{*}{ Gender $^{a}$} & Male & 45.18 & 45.54 & 43.48 \\
\hline & Female & 54.57 & 54.15 & 56.52 \\
\hline \multirow[t]{6}{*}{ Age group (years old) } & $18-25$ & 26.90 & 27.38 & 24.64 \\
\hline & $26-35$ & 41.37 & 42.15 & 37.68 \\
\hline & $36-45$ & 20.30 & 21.85 & 13.04 \\
\hline & $46-55$ & 7.87 & 5.54 & 18.84 \\
\hline & $56-65$ & 3.05 & 3.08 & 2.90 \\
\hline & Over 65 & 0.51 & 27.38 & 2.90 \\
\hline \multirow[t]{7}{*}{ Education level } & No formal education & 1.02 & 1.23 & 0 \\
\hline & Primary school & 0 & 0 & 0 \\
\hline & Secondary school & 3.05 & 3.38 & 1.45 \\
\hline & High school & 15.48 & 16.62 & 10.14 \\
\hline & $\begin{array}{l}\text { Three-year or under college } \\
\text { diploma/certificate }\end{array}$ & 29.19 & 30.15 & 24.64 \\
\hline & Bachelor degree & 40.61 & 42.77 & 30.43 \\
\hline & Post graduate degree & 10.66 & 5.85 & 33.33 \\
\hline
\end{tabular}




\begin{tabular}{|c|c|c|c|c|}
\hline Factor & Category & $\begin{array}{l}\text { Combined visitors } \\
\quad(n=394)\end{array}$ & $\begin{array}{l}\text { Vietnamese visitors } \\
\qquad(n=325)\end{array}$ & Foreign visitors $(n=69)$ \\
\hline \multirow[t]{8}{*}{ Occupation } & Civil servant & 16.75 & 18.46 & 8.70 \\
\hline & $\begin{array}{l}\text { Manager/owner of business/self- } \\
\text { employed }\end{array}$ & 23.86 & 24.62 & 20.29 \\
\hline & Staff and profession & 36.80 & 34.15 & 49.28 \\
\hline & Student & 14.47 & 14.15 & 15.94 \\
\hline & Fisherman/farmer & 3.55 & 4.31 & 0 \\
\hline & Retired & 2.54 & 2.15 & 4.35 \\
\hline & Unemployed/homemaker & 1.02 & 0.92 & 1.45 \\
\hline & Other & 1.02 & 1.23 & 0 \\
\hline \multirow[t]{6}{*}{ Marriage status } & Single/never married & 36.29 & 34.15 & 46.38 \\
\hline & Engaged & 4.57 & 4.92 & 2.90 \\
\hline & Married & 55.33 & 59.69 & 34.78 \\
\hline & De facto relationship & 2.79 & 0.62 & 13.04 \\
\hline & Divorced/separated & 0.76 & 0.31 & 2.90 \\
\hline & Widow/widower & 0.25 & 0.31 & 0 \\
\hline \multirow{12}{*}{$\begin{array}{l}\text { Household monthly gross } \\
\text { income }^{b} \text { (mil. VND) }\end{array}$} & $<5$ & & 0.62 & \\
\hline & $5-10$ & & 3.08 & \\
\hline & $10-15$ & & 23.69 & \\
\hline & $15-20$ & & 30.15 & \\
\hline & $20-25$ & & 18.15 & \\
\hline & $>25$ & & 24.31 & \\
\hline & $<45$ & & & 17.65 \\
\hline & $45-90$ & & & 30.88 \\
\hline & $90-135$ & & & 17.65 \\
\hline & $135-180$ & & & 8.82 \\
\hline & $180-225$ & & & 10.29 \\
\hline & $>225$ & & & 14.71 \\
\hline
\end{tabular}

aVietnamese visitors $n=324$; ${ }^{b}$ The income values of foreign visitors were converted from USD into VND; foreign visitors $n=68$

Table 3 shows visitors' motivations for their WTP for conservation of the CLC MPA. The results show that the visitors identified environmental quality improvement and conservation/preservation as the most important motivations for contributing to CLC MPA conservation (means 4.37 and 4.23, respectively). The results indicate that the "Yes" visitors are aware of their conservation contribution to CLC MPA's environment and natural resources. "The entrance fee to the CLC MPA is lower than that of other MPAs and coastal recreational sites" had the lowest mean score (3.39). This means the cheap entrance fee was unlikely the reason why the visitors were willing to pay additional entrance fee for the CLC MPA conservation. 
Table 3. Surveyed visitors' motivations for their WTP for conservation of Cu Lao Cham Marine Protected Area

\begin{tabular}{|c|c|c|c|c|c|c|}
\hline Willingness To Pay motivation & Obs. & Median & Mean & S.D. & Min & Max \\
\hline Conserve and preserve the CLC MPA for future generations & 326 & 5 & 4.37 & 0.75 & 1 & 5 \\
\hline Want better facilities & 325 & 3 & 3.48 & 1.03 & 1 & 5 \\
\hline Get satisfaction from having paid to help preserve the MPA & 321 & 4 & 3.99 & 0.88 & 1 & 5 \\
\hline Improve environmental quality in the CLC MPA & 324 & 4 & 4.23 & 0.87 & 1 & 5 \\
\hline Want to pay more for CLC MPA management and for using recreational areas & 323 & 4 & 4.16 & 0.82 & 1 & 5 \\
\hline The entrance fee to the CLC MPA is lower than that of other MPAs and coastal recreational sites & 321 & 3 & 3.39 & 1.04 & 1 & 5 \\
\hline Want to contribute to local development & 324 & 3 & 3.54 & 0.99 & 1 & 5 \\
\hline The CLC MPA beauty deserves to be paid more for enjoying it & 324 & 4 & 3.97 & 0.88 & 1 & 5 \\
\hline Do not think much about my motivation for WTP & 325 & 3 & 3.97 & 0.93 & 1 & 5 \\
\hline
\end{tabular}

Table 4 presents the visitors' WTP, including zero payment, for conservation in the CLC MPA, in intervals, for the three different groups of visitors: combined, Vietnamese and foreign visitors. The results show $85 \%$ of the surveyed visitors were willing to pay a positive amount for conservation in the CLC MPA. The separate group figures are $78 \%$ of foreign visitors and $87 \%$ of Vietnamese visitors. This result is similar to Lindsey and Holmes's (2002) study ( $72 \%$ and $83 \%$, respectively) that investigated the WTP for the Hon Mun MPA in Vietnam. It is likely that more Vietnamese visitors want to contribute to MPA conservation in Vietnam than foreign visitors. Similarly, Tapsuwan's (2005) study also found that more domestic visitors were willing to pay a larger positive amount for conservation than foreign visitors ( $45.67 \%$ and $34.56 \%$, respectively) while scuba diving in the Mu Ko Similan Marine National Park, Thailand.

Table 4. Frequency and proportion of Willingness to Pay interval selection

\begin{tabular}{|c|c|c|c|c|c|c|}
\hline \multirow{2}{*}{ Interval bid (US\$) } & \multicolumn{2}{|c|}{ Combined } & \multicolumn{2}{|c|}{ Vietnamese visitors } & \multicolumn{2}{|c|}{ Foreign visitors } \\
\hline & Frequency & $\%$ & Frequency & $\%$ & Frequency & $\%$ \\
\hline $0-1.0$ & 59 & 14.97 & 44 & 13.54 & 15 & 21.74 \\
\hline $1.0-1.5$ & 112 & 28.43 & 111 & 34.15 & 1 & 1.45 \\
\hline $1.5-2.0$ & 56 & 14.21 & 53 & 16.31 & 3 & 4.35 \\
\hline $2.0-2.5$ & 50 & 12.69 & 43 & 13.23 & 7 & 10.14 \\
\hline $2.5-3.0$ & 22 & 5.58 & 21 & 6.46 & 1 & 1.45 \\
\hline $3.0-3.5$ & 16 & 4.06 & 9 & 2.77 & 7 & 10.14 \\
\hline $3.5-4.0$ & 8 & 2.03 & 8 & 2.46 & 0 & 0 \\
\hline $4.0-4.5$ & 9 & 2.28 & 8 & 2.46 & 1 & 1.45 \\
\hline $4.5-5.0$ & 17 & 4.31 & 12 & 3.69 & 5 & 7.25 \\
\hline $5.0-5.5^{\star}$ & 32 & 8.12 & 11 & 3.38 & 21 & 30.43 \\
\hline $5.5+\star \star$ & 13 & 3.3 & 5 & 1.54 & 8 & 11.59 \\
\hline
\end{tabular}

* Visitors who chose a US\$ 5.0 bid had a higher bound WTP of US\$5.5.

** Visitors who chose a bid over US\$5.0 were assumed to have a lower bound WTP of US\$5.5.

The WTP models in this study use a mix of dummy, continuous and five-point Likert scales variables. The probability of the visitors' WTP for an additional entrance fee to visit the CLC MPA was modelled as a function of the visitors' characteristics, their perceptions of environmental protection and conservation, their environmental education 
awareness as well as their attitudes toward the entrance fee and the quality of nature in the CLC MPA. Table 5 reports the estimated coefficient values, robust standard errors and marginal effects of three WTP models for Vietnamese, foreign and both foreign and Vietnamese visitors. We used the conditional marginal effects of these models to examine the power of the effect of predictor factors on visitors' WTP. These models were estimated separately with different observation samples. Model 1 analysed Vietnam and foreign visitors' WTP. Model 2 analysed Vietnamese visitors' WTP. Model 3 analysed foreign visitors' WTP, regardless of whether they departed from Vietnam or overseas.

The income variable is a crucial factor in estimating WTP in CVM studies (e.g., Ahmed et al., 2007; Asafu-Adjaye and Tapsuwan, 2008; Samdin et al., 2010; Siew et al., 2015; Tonin, 2019; Trujillo et al., 2016; Wang and Jia, 2012). In this analysis, the income variable is positive and statistically significant in Models 1 and 2 at the $5 \%$ and $1 \%$ levels, respectively. This implies that the income variable plays a significant role in the WTP of Vietnamese and combined visitors. However, the insignificant income variable in Model 3 means that income is not an important factor for foreign visitors' WTP for conservation efforts in the CLC MPA. This finding is similar to Piriyapada and Wang's (2015) study that investigated differences in WTP between Thai and foreign visitors for resource protection in the Ko Chang Marine National Park. Their results show that the income variable is statistically significant only in single bounded and doublebounded dichotomous choice models of domestic visitors (at the $5 \%$ level). The positive income sign is the same as previous studies (e.g., Bateman et al., 2005; Landry et al., 2018; Yoo and Yang, 2001). The result indicates that visitors with higher incomes (in Models 1 and 2), are likely to pay more for conservation efforts in the CLC MPA. A one unit increase in income increases visitors' WTP by approximately $0.015 \%$ and $0.24 \%$ in Models 1 and 2 , respectively. In other words, if visitors' monthly income increases by US $\$ 100$, their WTP will rise by $1.5 \%$ and $24 \%$, respectively.

Only the variables relating to entrance fee (efrating and efincrease) are statistically significant in all three models (see Table 5). Rating the entrance fee negatively and significantly affects the visitors' WTP at the $1 \%$ level, which implies that, regardless of Vietnamese, non-Vietnamese, or combined visitors, they will pay less for conservation if they think that the current entrance fee is very expensive. In other words, if visitors rate the entrance price at a higher point (on a five-point Likert scale), their WTP for conservation decreases proportionally by 0.738 to 1.05 (or from $73.8 \%$ to over $100 \%$ ). The entrance fee is used as a proxy for the partial cost of visiting the MPA. The higher visitors perceive the cost of visiting the CLC MPA, the lower the probability that they will pay an additional amount for conservation efforts in the CLC MPA. In contrast, the importance of increasing an entrance fee is positive and statistically significant at $5 \%, 10 \%$, and $5 \%$ in Models 1, 2, and 3, respectively. This variable investigates visitors' awareness of conservation and environmental protection in the CLC MPA using an increased entrance fee. The result reveals that visitors with higher scores in the entrance fee increase will contribute more toward conservation. In other words, a one unit increase in the visitors' entrance fee score raises their WTP by $14 \%, 12.5 \%$ and $48.8 \%$ (for combined, Vietnamese and non-Vietnamese visitors, respectively). 
Table 5. Generalised Linear Models for WTP for conservation in the Cu Lao Cham Marine Protected Area

\begin{tabular}{|c|c|c|c|c|c|c|c|}
\hline \multirow{2}{*}{ Variable } & \multirow{2}{*}{ Description } & \multicolumn{2}{|c|}{$\begin{array}{l}\text { Combined visitors } \\
\quad \text { (Model 1) }\end{array}$} & \multicolumn{2}{|c|}{$\begin{array}{l}\text { Vietnamese visitors } \\
\quad \text { (Model 2) }\end{array}$} & \multicolumn{2}{|c|}{$\begin{array}{l}\text { Foreign visitors } \\
\quad \text { (Model 3) }\end{array}$} \\
\hline & & Coefficient & $\begin{array}{c}\text { Marginal } \\
\text { effect }\end{array}$ & Coefficient & $\begin{array}{c}\text { Marginal } \\
\text { effect }\end{array}$ & Coefficient & $\begin{array}{c}\text { Marginal } \\
\text { effect }\end{array}$ \\
\hline \multirow[t]{2}{*}{ inc } & \multirow[t]{2}{*}{ Monthly individual income (US\$) } & $7.17 \mathrm{e}-05^{\star \star}$ & $\begin{array}{l}1.505 \mathrm{e}- \\
04\end{array}$ & $0.0013^{\star \star \star}$ & $\begin{array}{l}2.363 e- \\
03\end{array}$ & $-3.03 e-05$ & $\begin{array}{l}-9.45 \mathrm{e}- \\
05\end{array}$ \\
\hline & & $(3.39 \mathrm{e}-05)$ & & $(3.3 e-04)$ & & $(3.58 \mathrm{e}-05)$ & \\
\hline \multirow[t]{2}{*}{ efrating } & \multirow[t]{2}{*}{ The rate of entrance fee. 1 = very cheap; $5=$ very expensive } & $-0.402^{\star \star \star}$ & -0.844 & $-0.390 * \star \star$ & -0.738 & 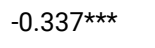 & -1.050 \\
\hline & & $(0.0434)$ & & $(0.0529)$ & & $(0.0798)$ & \\
\hline \multirow[t]{2}{*}{ manager } & \multirow{2}{*}{$\begin{array}{l}1=\text { If visitors are manager, owner of business or self-employed; } 0 \\
=\text { otherwise }\end{array}$} & 0.166 ** & 0.365 & $0.130^{\star}$ & 0.255 & 0.150 & 0.490 \\
\hline & & $(0.0688)$ & & $(0.0701)$ & & $(0.194)$ & \\
\hline \multirow[t]{2}{*}{ secondary } & \multirow{2}{*}{$\begin{array}{l}1=\text { If visitor's highest education is secondary school; } 0= \\
\text { otherwise }\end{array}$} & $-0.409 * \star$ & -0.713 & -0.238 & -0.404 & $-1.793^{\star \star \star}$ & -2.665 \\
\hline & & $(0.173)$ & & $(0.165)$ & & $(0.109)$ & \\
\hline \multirow[t]{2}{*}{ qltybeach } & \multirow{2}{*}{$\begin{array}{l}\text { Visitors' assessment on quality of CLC MPA beaches }(1=\text { very } \\
\text { poor; } 5=\text { very good })\end{array}$} & 0.00906 & 0.019 & -0.0237 & -0.045 & $0.242^{\star \star}$ & 0.754 \\
\hline & & $(0.0445)$ & & $(0.0469)$ & & $(0.106)$ & \\
\hline \multirow[t]{2}{*}{ envact } & \multirow{2}{*}{$\begin{array}{l}1=\text { If visitors participate in environmental protection activities; } 0= \\
\text { otherwise }\end{array}$} & 0.121 ** & 0.257 & $0.164^{\star \star}$ & 0.312 & 0.0993 & 0.316 \\
\hline & & $(0.0604)$ & & $(0.0644)$ & & $(0.166)$ & \\
\hline \multirow[t]{2}{*}{ valueCLC } & \multirow{2}{*}{$\begin{array}{l}1=\text { if jobs and foreign exchange are the most important value } \\
\text { provided by the CLC MPA; } 0=\text { otherwise }\end{array}$} & -0.392 & -0.682 & $0.215^{\star \star \star}$ & 0.455 & $-1.371^{\star \star \star}$ & -2.372 \\
\hline & & $(0.479)$ & & $(0.0619)$ & & $(0.283)$ & \\
\hline \multirow[t]{2}{*}{ efincrease } & \multirow{2}{*}{$\begin{array}{l}\text { Increasing the entrance fee to help improve conservation and } \\
\text { environmental protection in the CLC MPA ( } 1=\text { less important; } 5= \\
\text { most important) }\end{array}$} & $0.0667 * \star$ & 0.140 & $0.0659 *$ & 0.125 & $0.157^{\star \star}$ & 0.488 \\
\hline & & $(0.0335)$ & & $(0.0351)$ & & $(0.0767)$ & \\
\hline \multirow[t]{2}{*}{ ecoedu } & \multirow{2}{*}{$\begin{array}{l}\text { Enhancing eco-education for tourists ( } 1 \text { = less important; } 5 \text { = } \\
\text { most important) }\end{array}$} & $0.0775^{\star \star}$ & 0.163 & 0.0436 & 0.082 & 0.304 ** & 0.946 \\
\hline & & $(0.0369)$ & & $(0.0374)$ & & $(0.130)$ & \\
\hline \multirow{2}{*}{\multicolumn{2}{|c|}{ Constant }} & $1.094^{\star \star \star}$ & & $0.972^{\star \star \star}$ & & -0.986 & \\
\hline & & $(0.319)$ & & $(0.376)$ & & $(0.874)$ & \\
\hline \multicolumn{2}{|l|}{ Obs } & 394 & & 325 & & 69 & \\
\hline \multicolumn{2}{|l|}{ LL } & -686.21 & & -532.47 & & -147.42 & \\
\hline \multicolumn{2}{|l|}{$x^{2}$} & $193.32^{\star \star \star}$ & & $125.82^{\star \star \star}$ & & $1353.78^{\star \star *}$ & \\
\hline \multicolumn{2}{|l|}{ AIC } & 1392.427 & & 1082.932 & & 310.847 & \\
\hline \multicolumn{2}{|c|}{ WTP non-parametric estimates } & 2.24 & & 1.98 & & 3.47 & \\
\hline \multicolumn{2}{|l|}{ (95\% C.I.) } & $(2.09-2.4)$ & & $(1.84-2.12$ & & $(2.99-3.95)$ & \\
\hline WTP param & etric estimates & 2.26 & & 1.99 & & 3.56 & \\
\hline (95\% C.I.) & & $(2.16-2.37$ & & $(1.92-2.0$ & & $(3.13-3.99)$ & \\
\hline
\end{tabular}

Robust standard errors in parentheses

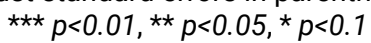

Visitors believe that eco-education enhancement for visitors will have a positive marginal effect on their WTP, by $16.3 \%$ and $94.6 \%$ in Models 1 and 3, respectively (Table 5). Like Machairas and Hovardas (2005), and Wang and Jia (2012), this study suggests that environmental/ecological education for visitors or MPA users plays an important role in maintaining the quality of nature and contributing to the biodiversity of natural parks or protected areas. Enhancement of environmental education not only helps reduce users' impact on the environment but also strengthens their 
environmental protection awareness. Enhancement of eco-education for visitors agrees with what the local government is doing in the CLC MPA such as visitors are not being allowed to bring any plastic bags to the island. However, the use of plastic bags is not the only issue created by increased visits to the CLC MPA. There are also problems related to waste disposal and overcrowding because of the increased number of visitors.

Although visitors agreed on the necessity of enhancing visitors' eco-education, Vietnamese and foreign visitors have different opinions on the most important value provided by the CLC MPA. Visitors' WTP was affected in opposite directions in Models 2 and 3 (significant at 1\% level) depending on what the most important value of the MPA that the visitors chose. If foreign visitors think that the most important factors are job creation and increased foreign exchange in the CLC MPA, then their WTP for conservation efforts declines. The results may also suggest that the CLC MPA residents and management board that rely on resources from the CLC MPA, and tourism, have enough revenue to cover their living expenses, their conservation programmes and other management duties. In turn, foreign visitors felt it was not necessary to pay an additional amount for conservation efforts. However, the Vietnamese visitors' perception differs. If job creation and foreign exchange are considered the most important features of the CLC MPA, Vietnamese visitors will contribute approximately $45.5 \%$ more for conservation through an additional entrance fee. Like previous studies (e.g., Babier et al., 1997; Cesar, 2000; Seenprachawong, 2002), we consider policy related to the marine tourism industry. Vietnamese visitors have seen the destructive impacts of increased visitor numbers on various marine parks. Thus, many are willing to support conservation/preservation efforts associated with such areas. For example, Seenprachawong's (2002) study shows local respondents strongly disagreed that Thailand should increase the number of jobs by developing its forest, sea or land resources (which would damage the environment). Therefore, they are unlikely to support tourism if it means degrading the environment and depleting natural resources. However, foreign visitors in our study are willing to pay $75.4 \%$ more for conservation if they think that the quality of the beach in the CLC MPA will increase by one point (based on a five-point Likert scale). This finding implies that visitors were willing to pay more for that a better-quality beach/ecosystem.

\section{WTP Estimates}

Our results show $85 \%$ of surveyed visitors chose a positive bid value on their WTP for conservation in the CLC MPA. This means that the major visitors were willing to pay an additional amount over the current entrance fee when they visit the CLC MPA. The results from the log-normal regressions (see Table 5) indicate that the WTP depended on the group of visitors (combined, Vietnamese or foreign visitors). The differences between the mean WTP of the three different groups of visitors are shown in Table 5. Foreign visitors were willing to contribute most towards conservation efforts (US\$3.56 per person per visit). Vietnamese visitors were willing to pay approximately $43 \%-44 \%$ less than the foreign visitors (US\$1.99 per person per visit).

\section{Conclusion}

The number of visitors travelling to the CLC MPA has increased dramatically over the last 10 years (approximately $46 \%$ annually between 2008 and 2018). The total number of people visiting the CLC MPA in 2018 approached 400,000, which was 20 times higher than the numbers in 2008 (Nguyen, 2019). CLC MPA receives over 3,000 visitors daily during the tourism season, which is higher than the number of residents on the islands $(3,000)$ ( $N g o c, 2018)$. Tourism development has contributed financially to the management of the CLC MPA, conservation programmes, and to local residents who lost their income through the establishment of the MPA. However, it has also created pressure on the biodiversity of the 
CLC MPA and caused environmental damage (e.g., degradation of the beaches and coral reefs). The question is, if the MPA management board and local authorities increase the current entrance fee based on the surveyed visitors' mean WTP for conservation, would this decrease the number of visitors, and/or impact the park's financial sustainability and/or conservation activities?

The WTP estimates from the CVM models reveal that the visitors were willing to pay a positive amount in addition to the current entrance fee to visit CLC MPA. This implies that they are likely to contribute more for the conservation of the CLC MPA through a new entrance fee. Policy makers could introduce a new fee system. A two-tier two-level system may be appropriate if authorities want to keep the number of visits the same (or decrease the total number of visits) but ensure that their funds for management and conservation programmes remain the same. One way to achieve this would be to charge foreign visitors a higher entrance fee and offer domestic and local visitors a reduced rate. Children and senior citizens could also be offered a $50 \%$ reduced entrance fee.

The mean WTP was used to predict the total benefit of the CLC MPA from the proposed entrance fee (the current entrance fee topped up with the mean WTP value); the current entrance fee uses three growth rates $(2.9 \%, 1 \%$ and $0 \%)$ of the total number of visitors. The results shows that the total revenue from the proposed entrance fee is approximately 2.5 times higher than that of the current entrance fee over the next 10 years. The total revenue from the proposed entrance fee with zero percent growth rate is still higher than that using the current entrance fee with $2.9 \%$ annual growth rate over 10 years from 2020 - 2029 (at a discount rate of 3.88\% per year). This result indicates that if the proposed entrance fee were introduced, the CLC MPA management would not only have sufficient funds, but also that the number of visitors may decline slightly, which would reduce some of the pressure on the environment, natural resources and coral reefs.

MPAs are established to conserve marine resource biodiversity. However, they need sufficient funds for their management and conservation programmes. According to Walton et al. (2015), MPAs in Vietnam are under financial deficit though they receive millions of visits per year. Their budget mainly comes from local and central government, and non-government organisations (Vo, 2020; Walton et al., 2015), which are insufficient for the MPAs' management and conservation programmes in the long-term. Meanwhile, eco-tourism development promises to generate a sustainable source of financing to the MPAs. Charging an entrance fee or increasing an entrance fee to the visitors from a nominal amount could help local communities capture scarce rental revenue from resources that they no longer have access to when MPAs are established. The entrance fee scheme implemented in each MPA depends on information supplied by the WTP analysis of the particular MPA or other successful MPA entrance fee systems. Based on the WTP for conservation of the Cu Lao Cham MPA, other MPAs in Vietnam may propose their own entrance fee system. A user fee also enables local authorities and the MPA management boards to manage the number of visitors and minimise the risk or damage to MPAs from tourism.

\section{Conflict of Interest Statement}

The authors agree that this research was conducted in the absence of any self-benefits, commercial or financial conflicts and declare absence of conflicting interests with the funders. 


\section{Acknowledgements}

This study is a part of a PhD research at Lincoln University, New Zealand. The correspondent author is grateful to VIED and Thuongmai University for the Ph.D study funding and support. The authors would like to extend their sincere thanks all respondents for their participation in the study and staffs of $\mathrm{Cu}$ Lao Cham marine protected area for their support during the study survey.

\section{Endnotes}

1. Int.\$ (international dollar), or the Geary-Khamis dollar, is a hypothesised currency unit the authors used to unify all values across countries in one currency. This currency is based on the purchasing power parity (PPP) that one US dollar could buy in the US at a certain time. Conversion of this currency to other countries' currency is possible only by using the country's PPP, not the market exchange rate. 1 Int.\$=1 USD (de Groot et al., 2012).

\section{References}

Ahmed, M., Chong, C.K., Cesar, H., 2005. Economic Valuation and Policy Priorities for Sustainable Management of Coral Reefs (Eds.). WorldFish Center, Penang, Malaysia.

Ahmed, M., Umali, G.M., Chong, C.K., Rull, M.F., Garcia, M.C., 2007. Valuing recreational and conservation benefits of coral reefs-the case of Bolinao, Philippines. Ocean Coast Manag. 50(1): 103-118.

Akhter, S., Yew, T.S., 2013. Economic valuation of marine protected areas: A review of studies in Southeast Asia. Int. j. soc. sci. 13(01): 1-16. Arin, T., Kramer, R.A., 2002. Divers' willingness to pay to visit marine sanctuaries: an exploratory study. Ocean Coast Manag. 45(2): 71-183. Asafu-Adjaye, J., Tapsuwan, S., 2008. A contingent valuation study of scuba diving benefits: Case study in Mu Ko Similan Marine National Park, Thailand. Tour. Manag. 29(6): 1122-1130.

Babier, E.B., Acreman, M., Knowler, D., 1997. Economic valuation of wetlands : a guide for policy makers and planners. Ramsar Convention Bureau, Gland, Switzerland.

Bateman, I., Cooper, P., Georgiou, S., Navrud, S., Poe, G.L., Ready, R.C., ... Vossler, C.A., 2005. Economic valuation of policies for managing acidity in remote mountain lakes: Examining validity through scope sensitivity testing. Aquat. Sci. 67(3): 392-392.

Brown, P.C., 2011. Livelihood change around marine protected areas in Vietnam: A case study in Cu Lao Cham. ChATSEA Working Papers 16, Université de Montréal, Montreal, Quebec, Canada.

Cameron, T.A., Huppert, D.D., 1989. OLS versus ML estimation of non-market resource values with payment card interval data. J Environ Econ Manage. 17(3): 230-246.

Carlsson, F., Frykblom, P., Liljenstolpe, C., 2003. Valuing wetland attributes: an application of choice experiments. Ecol Econ. 47(1): 95-103.

Cesar, H., 2000. Collected Essays on the Economics of Coral Reefs (Ed.). Sweden: CORDIO.

Chen, W., Hong, H., Liu, Y., Zhang, L., Hou, X., Raymond, M., 2004. Recreation demand and economic value: An application of travel cost method for Xiamen Island. China Econ. Rev. 15(4): 398-406.

Christie, M., Remoundou, K., Siwicka, E., Wainwright, W., 2015. Valuing marine and coastal ecosystem service benefits: Case study of St Vincent and the Grenadines' proposed marine protected areas. Ecosyst. Serv. 11: 115-127. 
Cicin-Sain, B., 2014. Goal 14: conserve and sustainably use the oceans, seas and marine resources for sustainable development. UN Chronicle, $51,32+$.

Costanza, R., d'Arge, R., de Groot, R., Farber, S., Grasso, M., Hannon, B., ... van den Belt, M., 1997. The value of the world's ecosystem services and natural capital. Nature. 387(6630): 253-260.

de Groot, R., Brander, L., van der Ploeg, S., Costanza, R., Bernard, F., Braat, L., ... van Beukering, P., 2012. Global estimates of the value of ecosystems and their services in monetary units. Ecosyst. Ser., 1(1): 50-61.

Dixon, J., Scura, L.F., van't Hof, T., 2000. An economic and ecological analysis of the Bonaire marine park, in: Cesar H.S.J. (Ed.), Collected Essays on the Economics of Coral Reefs, CORDIO, Department for Biology and Environmental Sciences, Kalmar University, Sweden, pp. 158165.

Emerton, L., 1999. Economic Tools for the Management of Marine Protected Areas in Eastern Africa. IUCN - The World Conservation Union, Eastern Africa Regional Office, Nairobi, Kenya.

Geleto, A.K., 2011. Contingent valuation technique: A review of literature. ISABB J. Health Environ. sci. 1(1): 8-16.

Ghosh, P.K., Mondal, M.S., 2013. Economic valuation of the non-use attributes of a south-western coastal wetland in Bangladesh. J. Environ. Plan. Manag. 56(9): 1403-1418.

Goodman, S.L., Seabrooke, W., Jaffry, S.A., 1998. Considering Conservation Value in Economic Appraisals of Coastal Resources. J. Environ. Plan. Manag. 41(3): 313-336.

Hackl, F., Pruckner, G., 1999. On the Gap between Payment Card and Closed-Ended CVM-Answers. Appl. Econ. 31; 733-742.

Hall, D.C., Hall, J.V., Murray, S.N., 2002. Contingent valuation of marine protected areas: Southern California rocky intertidal ecosystems. Nat. Resour. Model. 15(3): 335-368.

Kerr, G.N., 2001. Contingent valuation elicitation effects: Revisiting the payment card. Paper presented to the Australian Agricultural and Resource Economics Society, 23-25 January 2001, Adelaide, Australia.

Landry, C.E., Shonkwiler, J.S., Whitehead, J.C., 2018. Economic values of coastal erosion management: Joint estimation of use and passive use values with recreation demand and contingent valuation data. Department of Economics Working Paper 18-09, Appalachian State University.

Lange, G.-M., Jiddawi, N., 2009. Economic value of marine ecosystem services in Zanzibar: Implications for marine conservation and sustainable development. Ocean Coast Manag. 52(10): 521-532.

Latinopoulos, D., Mallios, Z., Latinopoulos, P., 2016. Valuing the benefits of an urban park project: A contingent valuation study in Thessaloniki, Greece. Land use policy. 55: 130-141.

Ledoux, L., Turner, K., 2002. Valuing ocean and coastal resources: a review of practical examples and issues for further action. Ocean Coast Manag. 45: 583-616.

Lindsey, G., Holmes, A., 2002. Tourist support for marine protection in Nha Trang, Viet Nam. J. Environ. Plan. Manag. 45(4): 461-480.

Lipton, D. W., Wellman, K., Sheifer, I. C., Weiher, R. F., 1995. Economic Valuation of Natural Resources_A Handbook for Coastal Resource Policymakers. NOOA Coastal Ocean Office, Silver Spring, MD.

Liu, W.Y., Chen, P.Z., Hsieh, C.M., 2019. Assessing the recreational value of a national forest park from ecotourists' perspective in Taiwan. Sustainability. 11(15): 4084-.

Long, N.V., Tuan, V.S., Ben, H.X., Hoang, P.K., Tuyen, H.T., Vy, N.X., Kiem, D.T., 2008. Biodiversity and environmental quality in Cu Lao Cham marine protected area: 2004 - 2008 - Final report. Vietnam Acedemy of Science and Technology, Institute of Oceanography, Nha Trang.

Machairas, I., Hovardas, T., 2005. Determining visitors' dispositions toward the designation of a Greek national park. Environ Manage. 36(1):73-88. 
Mahieu, P.-A., Riera, P., Giergiczny, M., 2012. Determinants of willingness-to-pay for water pollution abatement: A point and interval data payment card application. J. Environ. Manage. 108: 49-53.

Martínez, M.L., Intralawan, A., Vázquez, G., Pérez-Maqueo, O., Sutton, P., Landgrave, R., 2007. The coasts of our world: Ecological, economic and social importance. Ecol Econ. 63(2-3): 254-272.

Mathieu, L.F., Langford, I.H., Kenyon, W., 2003. Valuing marine parks in a developing country: a case study of the Seychelles. Environ Dev Econ. 8(2): 373-390.

Ministry of Fishery, Danida, 2005. Sustainable livelihoods in and around marine protected areas. Ministry of Fisheries/DANIDA, Hanoi, Vietnam. Ngoc, Q.T.K., 2018. Impacts on the ecosystem and human well-being of the marine protected area in Cu Lao Cham, Vietnam. Mar Policy. 90: 174-183.

Nguyen, V.H., 2019. Tourism and poverty: Perspectives and experiences of local residents in Cu Lao Cham MPA, Vietnam. Tour. Mar. Environ. 14(3): 179-197.

Peters, H., Hawkins, J.P., 2009. Access to marine parks: A comparative study in willingness to pay. Ocean Coast Manag. 52(3): $219-228$.

Piriyapada, S., Wang, E., 2015. Modeling willingness to pay for coastal tourism resource protection in Ko Chang marine national park, Thailand. Asia Pac. J. Tour. Res. 20(5): 1-26.

Rolfe, J., Gregg, D., 2012. Valuing beach recreation across a regional area: The Great Barrier Reef in Australia. Ocean Coast Manag. 69: 282290.

Samdin, Z., Abdul Aziz, Y., Radam, A., Yacob, M.R. 2010. Factors influencing the willingness to pay for entrance permit: The evidence from Taman Negara national park. J. Sustain. Dev. 3(3): 212-220.

Seenprachawong, U., 2002, An economic valuation of coastal ecosystems in Phang Nga Bay, Thailand. Research Report, Environment and Economics Program for South East Asia, International Development Research Center Ottawa, Canada.

Seenprachawong, U., 2005. An economic analysis of coral reefs in the Andaman Sea of Thailand, in: Ahmed, M., Chong, C.K., Cesar, H. (Ed.), Economic Valuation and Policy Priorities for Sustainable Management of Coral Reefs. WorldFish Center, Penang, Malaysia, pp.79-83.

Sekhar, N.U., 2005. Integrated coastal zone management in Vietnam: Present potentials and future challenges, Ocean Coast Manag. 48(9-10): 813-827.

Siew, M.K., Yacob, M.R., Radam, A., Adamu, A., Alias, E.F., 2015. Estimating willingness to pay for wetland conservation: A contingent valuation study of Paya Indah Wetland, Selangor Malaysia. Procedia Environ. Sci. 30: 268-272.

Tapsuwan, S., 2005. Valuing the willingness to pay for environmental conservation and management: a case study of scuba diving levies in Moo Koh Similan Islands Marine national park, Thailand. Paper presented at the Australian Conference of Economists, Australia.

Thang, H.C., Misdorp, R., Laboyrie, H., Pos, H., Zetten, R.v., Huan, N.N., 2011. Vietnam: a decade of coastal cooperation. From vulnerability assessment to integrated coastal zone management, from planning to implementation, in: Misdorp R. (Ed.), Climate of Coastal Cooperation, Coastal \& Marin Union. Leiden, the Netherlands.

Thur, S.M., 2004. Valuing recreational benefits in coral reef marine protected areas: an application to the Bonaire national marine park. Ph.D. thesis, University of Delaware, USA.

Tin, H.C., Uyen, N.T., Hieu, D.V., Ni, T.N.K., Tu, N.H.C., Saizen, I., 2019. Decadal dynamics and challenges for seagrass beds management in Cu Lao Cham marine protected area, central Vietnam. Environ. Dev. Sustain. 22: 7639-7660.

Togridou, A., Hovardas, T., Pantis, J.D., 2006. Determinants of visitors' willingness to pay for the national marine park of Zakynthos, Greece. Ecol Econ. 60(1): 308-319.

Tongson, E., Dygico, M., 2004. User fee system for marine ecotourism: The Tubbataha Reef experience. Coast Manage. 32(1): 17-23. 
Tonin, S., 2019. Estimating the benefits of restoration and preservation scenarios of marine biodiversity: An application of the contingent valuation method. Environ Sci Policy. 100: 172-182.

Tri, H.M., 2007. Survey report on income, environmental awareness and livelihood consultation to affected households. In Consultancy report to MOFI-DANIDA DCE Programme and Cham Island MPA Authority, Vietnam.

Trinh, C.M., 2006. Final Report on the Cu Lao Cham marine protected area project's activities (10/2003 - 9/2006). Hoi An, Quang Nam: People's Committee of Quang Nam Cham Islands MPA Management Board.

Trinh, C.M., 2008. Cu Lao Cham marine protected area management plan. Hoi An, Quang Nam: Quang Nam People Committee, Department of Agriculture and Rural Development, Cu Lao Cham Marine Protected Area Management Board.

Trujillo, J.C., Carrillo, B., Charris, C.A., Velilla, R.A., 2016. Coral reefs under threat in a Caribbean marine protected area: Assessing divers' willingness to pay toward conservation. Mar Policy. 68: 146-154.

Tuan, V. S., Long, N.V., Tuyen, H.T., Hoang, P.K., Hoa, N.X., Thom, P.V., ... Linberg, R., 2004. Marine habitats and resource surveys of Cu lao Cham marine protected area, Quang Nam Province, Vietnam. Support the MPA Network Project, Vietnam.

Vo, D.N., 2020. Viet Nam's national system of marine protected areas. APO. 5(1): 65-98.

Walton, A., Hang, T.T.M., Hien, B.T.T., Duong, K.T., Hien, N.B., Bac, P.V., Brunner, J., 2015. Vietnam marine protected area management effectiveness evaluation, IUCN, Gland, Switzerland.

Wang, P.-W., Jia, J.-B., 2012. Tourists' willingness to pay for biodiversity conservation and environment protection, Dalai Lake protected area: Implications for entrance fee and sustainable management. Ocean Coast Manag. 62: 24-33.

Xu, Z., Loomis, J., Zhang, Z., Hamamura, K., 2006. Evaluating the performance of different willingness to pay question formats for valuing environmental restoration in rural China. Environ Dev Econ. 11: 585-601.

Yeo, B.H., 2005. The recreational benefits of coral reefs: A case study of Pulau Payar marine park, Kedah, Malaysia, in: Ahmed, M., Chong, C.K., Cesar, H. (Ed.), Economic Valuation and Policy Priorities for Sustainable Management of Coral Reefs. WorldFish Cente, Penang, Malaysia, pp. $108-117$.

Yoo, S., Yang, H., 2001. Application of sample selection model to double-bounded dichotomous choice contingent valuation studies. Environ Resour Econ. 20(2): 147-163. 